\title{
Nematode parasites of marsupials and small rodents from the Brazilian Atlantic Forest in the State of Rio de Janeiro, Brazil
}

\author{
Delir Corrêa Gomes ${ }^{1,2,3}$, Rosane Pereira da Cruz ${ }^{1}$, \\ Joaquim Júlio Vicente ${ }^{1} \&$ Roberto Magalhães Pinto ${ }^{1,2}$
}

1 Laboratório de Helmintos Parasitos de Vertebrados, Departamento de Helmintologia, Instituto

Oswaldo Cruz. Avenida Brasil 4365, 21045-900 Rio de Janeiro, Brasil.

${ }^{2} \mathrm{CNPq}$ research fellow.

${ }^{3}$ Corresponding author. E-mail: dcgomes@ioc.fiocruz.br

\begin{abstract}
Nematodes from opossums and rodents captured in the Brazilian Atlantic Forest in the State of Rio de Janeiro, Brazil were studied. From the opossums Didelphis aurita Weid-Neuweid, 1826 and Philander opossum (Linnaeus, 1758) the following nematode species were recovered: Viannaia hamata Travassos, 1914, Aspidodera raillieti Travassos, 1913, Cruzia tentaculata (Rudolphi, 1819), Travassos, 1917, Turgida turgida (Rudolphi, 1819) Travassos, 1919, Gongylonemoides marsupialis (Vaz \& Pereira, 1934) Freitas \& Lent, 1937, Viannaia viannai Travassos, 1914, Spirura guianensis (Ortlepp, 1924) Chitwood, 1938 and from the rodents Akodon cursor (Winger, 1887), Nectomys squamipes (Brants, 1827), Oligoryzomys eliurus (Wagner, 1845) and Oryzomys intermedius (Leche, 1886): Hassalstrongylus epsilon (Travassos, 1937) Durette-Desset, 1971, Syphacia obvelata (Rudolphi, 1802) Seurat, 1916, S. venteli Travassos, 1937, Physaloptera bispiculata Vaz \& Pereira, 1935, Litomosoides carinii (Travassos, 1919) Vaz, 1934, Viannaia viannai, Hassalstrongylus epsilon, $H$. zeta (Travassos, 1937) Durette-Desset, 1971, Stilestrongylus aculeata (Travassos, 1918) Durette-Desset, 1971 S. eta (Travassos, 1937) Durette-Desset, 1971. Highest worm burdens and prevalences were those related to Cruzia tentaculata in marsupials. Stilestrongylus aculeata was referred for the first time in Akodon cursor.
\end{abstract}

KEY WORDS. Helminths, mammals, prevalence.

The Brazilian Atlantic Forest is a formation distributed along the Brazilian coast, originally as a continuous belt from the State of Rio Grande do Norte to the State of Rio Grande do Sul, reaching about $1,100,000 \mathrm{~km}^{2}$; nowadays, this forest is restricted to only 5\% of its original area (AzEvEDo 1997).

Due to the great deforestation process that has been occurring, the fauna is continuosly being isolated in scattered remaining patches of the original forest and thus, many species are endangered. Nowadays, the urban expansion is the major menace to the forest (AzEvEDo 1997). The destruction rates are so alarming that in 1992 this ecosystem was considered a Biosphere reserve and its biodiversity regarded as a global product and thus, a stimulating development factor (CHAVEs 1997).

The protection of the Brazilian Atlantic Forest has to be conducted aiming at all environmental profiles (COPOBIANCO 1997). The autochthonous fauna consists mostly of mammals, birds and amphibians. There are 129 species of terrestrial mammals, of which $40 \%$ are endemic in cohabitation with about 160 bird species and 183 species of amphibians. Among the terrestrial mammals, there are 58 species of rodents and 23 of marsupials (FonseCa \& KierulfF 1989, AzEvedo 1997).

Recently, studies have been undertaken with these animals from the Brazilian Atlantic Forest in order to collect data, considering their ecological importance, as well as the role these animals play as reservoirs for sylvatic zoonoses that can affect man (Almeida et al. 1986, Bergalo 1994, Cerqueira et al. 1993, REY 1993).

Besides the systematic and taxonomic approaches, studies of the helminth fauna parasitizing these potential reservoirs of severe zoonoses, as schistosomiasis, are important to the screening of parasites infecting these hosts (Gomes 1979, Gomes et al. 1992, VICENTE et al. 1982).

Many marsupials and small wild rodents are part of this group, with peculiar habits and behavior, in a constant interrelation with the environment. This fact has been observed in some of their areas of occurrence, where schistosomiasis is more prevalent in rodents than in humans (RoDRIGUES-SILVA et al. 1992).

In the present paper, a helminth survey of two marsupial species Didelphis aurita Wied-Neuweid, 1826 and Philander 
opossum (Linnaeus, 1758) and four rodent species, Akodon cursor (Winge, 1887), Nectomys squamipes (Brants, 1827), Oligoryzomys eliurus (Wagner, 1845) and Oryzomys intermedius (Leche, 1886) from some localities of the Mata Atlântica is presented.

\section{MATERIALS AND METHODS}

The studied material was recovered during necropsies of small mammals, captured in dense tropical rain forest areas in the State of Rio de Janeiro (Figs 1-2) and was included in three groups: (a) samples received for identification, (b) collected samples (present authors) and (c) samples deposited in the Helminthological Collection of the Instituto Oswaldo Cruz (CHIOC).

The received samples (a) resulted from field work related to the "Project of small mammals from the Mata Atlântica" and expeditions that were part of the survey "Ecology and systematics of mammals from eastern Brazil", between 1990-1991 under the leadership of Dr. Rui Cerqueira, from the Laboratory of Vertebrates Ecology, Department of Animal Ecology, Universidade Federal do Rio de Janeiro (UFRJ), Brazil. These samples were collected in different localities of the State of Rio de Janeiro: São Pedro da Aldeia - Fazenda Cordeiro ( $22^{\circ} 51^{\prime} \mathrm{S}$, $\left.42^{\circ} 31^{\prime} \mathrm{W}\right)$; Casimiro de Abreu - Morro de São João ( $22^{\circ} 32^{\prime} \mathrm{S}$, $\left.42^{\circ} 02^{\prime} \mathrm{W}\right)$ and Fazenda União $\left(22^{\circ} 26^{\prime} \mathrm{S}, 42^{\circ} 02^{\prime} \mathrm{W}\right)$; Macaé Glicério ( $\left.22^{\circ} 14^{\prime} \mathrm{S}, 42^{\circ} 04^{\prime} \mathrm{W}\right)$; Angra dos Reis - Mambucaba (next to Mambucaba River) $\left(23^{\circ} 01^{\prime} \mathrm{S}, 44^{\circ} 31^{\prime} \mathrm{W}\right)$; Maricá - Reef

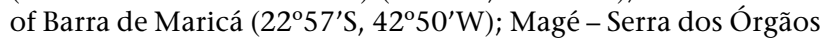
$\left(22^{\circ} 57^{\prime} \mathrm{S}, 43^{\circ} 01^{\prime} \mathrm{W}\right)$ - Pamparrão and Porteira Verde Valleys.

The animals were killed and the carcasses deposited in the Museu Nacional of Rio de Janeiro/UFRJ. Helminths were preserved in $10 \%$ formaldehyde, in labeled vials with data on locality of capture, date, and site of infection. Part of the material was represented by uncut viscera, also preserved in $10 \%$ formaldehyde; organs were removed from 24 specimens of $P h i-$ lander opossum, 14 from Didelphis aurita, 21 from Nectomys squamipes, five of Akodon cursor and five from Oryzomys intermedius; stomachs and intestines were investigated for helminths.

Helminth samples collected in the present study (b) were recovered from animals captured in the State of Rio de Janeiro: four specimens of Didelphis aurita in the municipality of Macaé, Glicério, Nossa Senhora da Glória farm $\left(22^{\circ} 14^{\prime} \mathrm{S}, 42^{\circ} 04^{\prime} \mathrm{W}\right)$; one Philander opossum, 4 Nectomys squamipes, seven Didelphis aurita and six Oryzomys intermedius in the Centro de Primatologia of the State of Rio de Janeiro, in the municipality of Guapimirim $\left(22^{\circ} 32^{\prime} \mathrm{S}, 42^{\circ} 59^{\prime} \mathrm{W}\right)$; 9 Akodon cursor in the district of Magé, Suruí, Santa Margarida farm $\left(22^{\circ} 40^{\prime} \mathrm{S}, 43^{\circ} 04^{\prime} \mathrm{W}\right)$.

Animals were captured with Sherman, Tomahaw and Movarte traps (live-trap-type), with $23 \times 13 \times 09 \mathrm{~cm}, 40 \times 15 \times$ $15 \mathrm{~cm}$ and $32 \times 18 \times 20 \mathrm{~cm}$, respectively, baited with manioca portions, mixed with peanut cream, banana, bacon and oat flour, identified by a color ribbon, numbered and distributed along pre-established tracks, $10 \mathrm{~m}$ from each other. Traps were checked and baits changed every morning. In the field, after capture, marsupials had their weight and sex verified and were individually kept in $40 \times 30 \mathrm{~cm}$ plastic cages with stainless steel fenced covers and wood shavings padding. Animals fed on Pedigree Champ® chow, banana, orange and filtered water from nursing bottles adapted to the covers. Cages were labeled with the number of the animal, track of capture, date, locality, sex and species.
The procedures referring to the rodents were similar, except for the food; they fed on Nuvilab ${ }^{\circledR}$ chow and were individually kept in $30 \times 18.5 \mathrm{~cm}$ cages.

Marsupials and rodents were killed in an ether chamber according to ethical procedures (APA 1989), either in the Laboratory of Helminth Parasites of Vertebrates or in the Laboratory of Biology and Schistosomiasis Control, Helminthology and Biology Departments, respectively, Instituto Oswaldo Cruz/ Fiocruz. Nematodes were fixed in hot AFA (acetic acid 2\%, formaldehyde $3 \%, 70^{\circ}$ ethanol $95 \%$ ).

Five males and five females/sample/host were selected for identification. Processing of nematodes for study, procedures for the attainment of "en face" glycerine-jelly mounts and "synlophe" mountings were described elsewhere (PInTo 1978, PINTO et al. 1994, 2002). Samples were deposited in the Helminthological Collection of the Oswaldo Cruz Institute (CHIOC).

Hosts were identified by Dr. Lena Geise from the Universidade do Estado do Rio de Janeiro (UERJ) that supplied the cariotypes of Akodon cursor and Oryzomys intermedius. Rodents captured by one of the authors (RPC) were identified by Dr. Cibele Rodrigues Bonvicino from the Instituto Nacional do Cancer (INCA)/Rio de Janeiro. NHR refers to New Host Record.

The prevalences and mean intensities are indicated in accordance to BUSH et al. (1997).

\section{RESULTS}

The present results are based on the characters that better identify the studied specimens, since most of them have recently been reported.

\section{Trichostrongyloidea, Viannaiidae, Viannaiinae}

\section{Viannaia hamata Travassos, 1914}

Host: Didelphis aurita Wied-Neuwied, 1826.

Site of infection: small intestine.

Locality: Glicério-Macaé, Rio de Janeiro.

Specimens deposited. CHIOC $\mathrm{n}^{\circ} 33472,33474,33477$ and 33586.

Remarks. Travassos (1914) proposed the genus Viannaia with the type $V$. viannai and also described $V$. conspicua, $V$. pussilla, V. hydrocheri and V. hamata. FreItas \& Lent (1935) analyzing specimens of $V$. hamata recovered from $D$. aurita, observed that males of this species can present, in the middle portion of the dorsal trunk of the copulatory bursa, numerous globular projections, randomly disposed and also the presence of pre-bursal papillae, overlooked in the original description. PINTO \& GOMES (1980) referred to $V$. hamata in D. marsupialis from the Amazon region. Guerrero (1985), studying Venezuelan marsupials, revised the genus Viannaia and redescribed $V$. hamata, adding new data on the morphology of female specimens. The prevalence of $V$. hamata was of $16 \%$ with a mean intensity of 16.2. The species was in coinfection with $A$. raillieti + C. tentaculata + Turgida turgida in $8 \%$ of the cases and to $A$. raillieti $+C$. tentaculata in $4 \%$ of the occurrences.

\section{Viannaia viannai Travassos, 1914}

Hosts. Philander opossum (Linnaeus, 1758), Akodon cursor (Winge, 1887).

Site of infection: small intestine. 

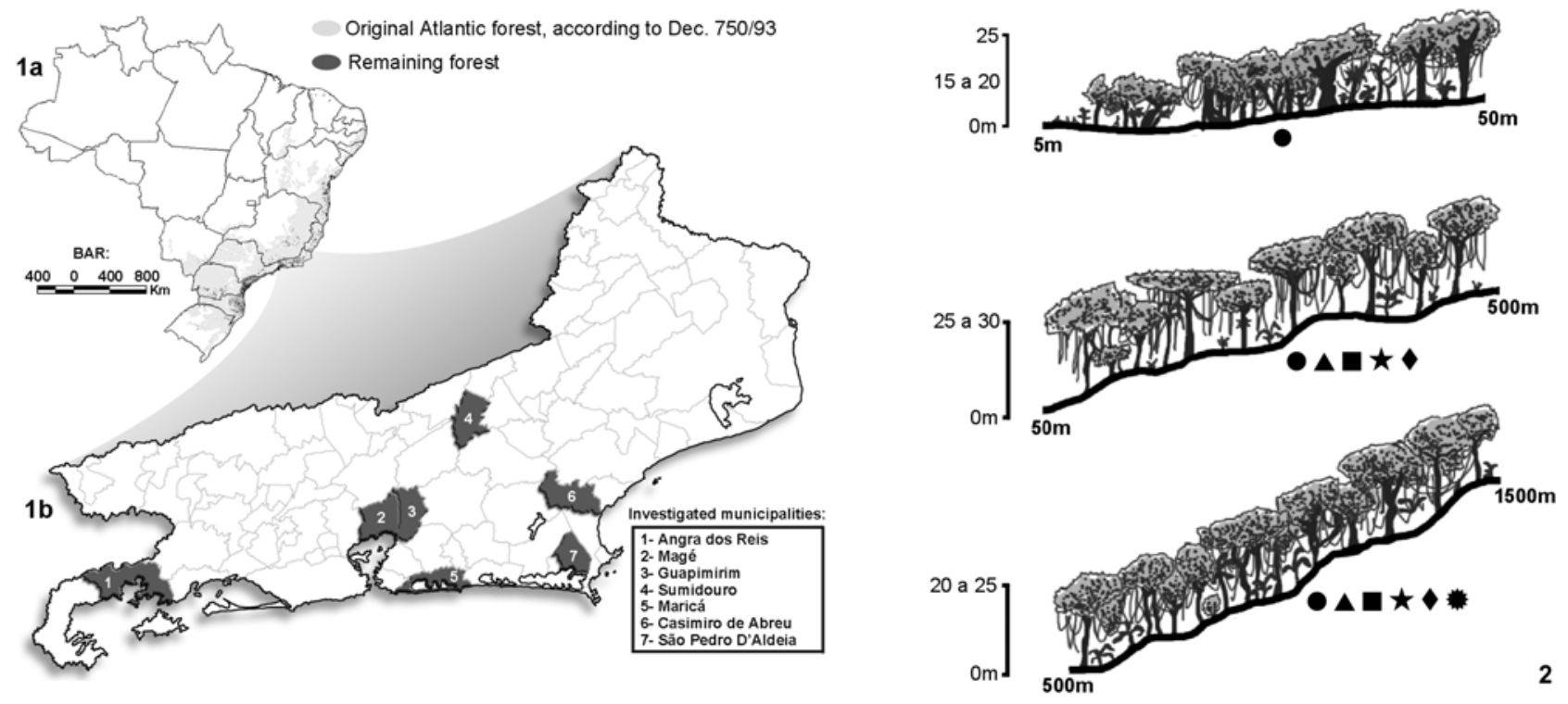

Figures 1-2. (1a) Distribuition of the Brazilian Atlantic Forest; (1b) capture in the State of Rio de Janeiro; (2) distribution of the investigated

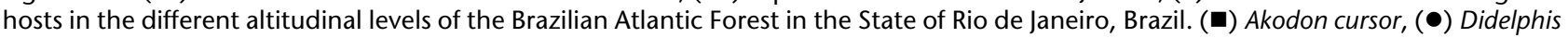

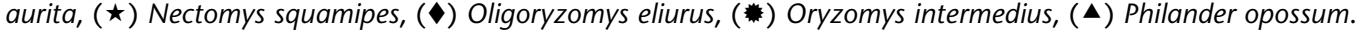

Localities. Morro São João-Casimiro de Abreu, Suruí Magé, Rio de Janeiro.

Specimens deposited. CHIOC $\mathrm{n}^{\circ} 35267$ and 35268.

Remarks. Proposed by Travassos (1914) as the type species of the genus, was restudied by DuRette-Desset (1968) that described the "synlophe" of this species as presenting $3 \mathrm{cu}-$ ticular longitudinal ventral ridges, directed towards the right side; besides, the author refers that trichostrongylid nematodes parasitizing American marsupials are grouped in two genera: Travassostrongylus Orloff, 1933 and Viannaia Travassos, 1914, considering Camerostrongylus Wolfgang, 1951 synonym of the former and Phylostrongylus Wolfgang, 1951, a synonym of the latter as well. The closest species to $V$. viannai is $V$. hamata that can be distinguished from $V$. viannai by the presence of an inconspicuous gubernaculum that, if overlooked can make the differentiation difficult. The prevalence of $V$. viannai alone in $P$. opossum was of $4 \%$ with a mean intensity of 11 and in coinfection with $A$. railliet $+C$. tentaculata, the prevalence was also of $4 \%$, with a mean intensity of 21 .

\section{Heligmonellidae, Nippostrongylinae}

\section{Hassalstrongylus epsilon (Travassos, 1937) Durette-Desset, 1971}

Hosts. Akodon cursor (Winger, 1887), Nectomys squamipes (Brants, 1827).

Site of infection: small intestine.

Localities. Mambucaba - Angra dos Reis, Rio de Janeiro Primatology Center, Guapimirim and Suruí - Magé, Rio de Janeiro.

Specimens deposited. CHIOC $\mathrm{n}^{\circ} 31608$ and 31882.

Remarks. Travassos (1937a) proposed the species as Longistriata epsilon; the "synlophe" was further described by DuRETTE-
Desset (1969) and later (1971) included by the same author in the genus Hassalstrongylus Durette-Desset, 1971.

In A. cursor, H. epsilon appeared alone with a prevalence of $8 \%$ and mean intensity of 16 whereas in $N$. squamipes the prevalence was of $28 \%$, mean intensity of 15 and appeared in $36 \%$ of the coinfection with $P$. bispiculata and in $4 \%$ of the other coinfection: P. bispiculata + Syphacia venteli; $L$. carinii $+P$. bispiculata.

\section{Hassalstrongylus zeta (Travassos, 1937) Durette-Desset, 1971}

Hosts. Akodon cursor (Winger, 1887), Oligoryzomys eliurus (Wagner, 1845), Oryzomys intermedius (Leche, 1886).

Site of infection: small intestine.

Localities. Rio de Janeiro Primatology Center, Guapimirim, Suruí-Magé, Rio de Janeiro.

Specimens deposited. CHIOC $\mathrm{n}^{\circ} 14314,14319,14326$, 14327, 14345, 14352 and 15748.

Remarks. The species was described by Travassos (1937a) as Longistriata zeta, recovered from Muridae hosts captured in Angra dos Reis, Rio de Janeiro and was also included in Hassalstrongylus Durette-Desset, 1971. In A. cursor, the prevalence of $\mathrm{H}$. zeta was of $28 \%$ with a mean intensity of 17.6 , alone in $24 \%$ of the cases. In O. eliurus, the prevalence was of $57.1 \%$, mean intensity of 10.7 , alone in $28.6 \%$ of the cases and in coinfection with Stilestrongylus eta in $14.3 \%$ and to $S$. eta in $7.1 \%$ of the occurrences. In O. intermedius the prevalence of $H$. zeta was of $54.5 \%$ and mean intensity of 45.7 . The species appeared alone in $9.1 \%$ of the cases.

\section{Stilestrongylus aculeata (Travassos, 1918) Durette-Desset, 1971}

Host: Akodon cursor (Winger, 1887) - NHR.

Site of infection: small intestine.

Locality: Suruí-Magé, Rio de Janeiro. 
Specimens deposited. CHIOC $\mathrm{n}^{\circ} 35266$.

Remarks. The species was described as Heligmosomum aculeatum by Travassos (1918), and was further transferred to the genus Stilestrongylus Durette-Desset, 1971. The "synlophe" is formed by 25 ridges directed from the left to the right in the dorsal side of the body and partially from the right to the left in the ventral region. The prevalence of $S$. aculeata was of $4 \%$ and mean intensity of 24 and occurred alone in $4 \%$ of the cases.

\section{Stilestrongylus eta (Travassos, 1937) Durette-Desset, 1971}

Host: Oligoryzomys eliurus (Wagner, 1845).

Site of infection: small intestine.

Locality: Suruí - Magé, Rio de Janeiro.

Specimens deposited. CHIOC $\mathrm{n}^{\circ}$ 14313, 14314 and 14326.

Remarks. This species was described by TRAVASSOS (1937a) as Longistriata eta and was re-allocated in the present genus by DURETTE-DESSET (1971). The prevalence of the species in O. eliurus was of 50\%, mean intensity of 11.1 , appearing alone in 7.1 of the cases and in coinfection with $\mathrm{H}$. zeta.

\section{Oxyuroidea, Oxyuridae, Syphaciinae}

\section{Syphacia obvelata (Rudolphi, 1802) Seurat, 1916 \\ Host: Akodon cursor (Winger, 1887). \\ Site of infection: large intestine.}

Localities. Morro de São João - Casimiro de Abreu, Serra dos Órgãos, Magé and Barra de Marica - Marica, Rio de Janeiro.

Specimens deposited. CHIOC $\mathrm{n}^{\circ}$ 14311, 15736 and 15741.

Remarks. This species was described by Rudolphi (1802) as Ascaris obvelata, that was further allocated as Syphacia obvelata by Seurat (1916). Neveu-Lemaire (1936) redescribed S. obvelata, presenting data on its geographical distribution. PINTO et al. (1994) in a major study of the helminth fauna of laboratory animals gave the prevalence of this species in inbred and outbred mice and fully figured $S$. obvelata, so that this pinworm could be identified also by those not acquainted to the finding of helminths during the development of experimental protocols using laboratory animals naturally infected with this common nematode, that can interfere in the final results, if undetected. Syphacia obvelata was only found in A. cursor, with a prevalence of $4 \%$ and mean intensity of 2 , and was not in coinfection with other species.

\section{Syphacia venteli Travassos, 1937}

Host: Nectomys squamipes (Brants, 1827).

Site of infection: large intestine.

Localities. Barra de Maricá - Maricá and Morro de São João - Casimiro de Abreu, Rio de Janeiro. 31606.

Specimens deposited. CHIOC $n^{\circ}$ 9739, 9740, 9883 and

Remarks. This species was described by Travassos (1937b) from the same host presently studied and was also referred by Quentin (1969) from Colombian cricetid rodents. Gomes \& VICENTE (1984) reported to the occurrence of $S$. venteli in $N$. squamipes, with a prevalence of $9.5 \%$ of the 42 examined host specimens. In the present study, the prevalence of the species was $4 \%$ (25 examined), with a mean intensity of 3 , appearing in coinfection with $P$. bispiculata $+H$. epsilon in $4 \%$ of the cases.

\section{Heterakoidea, Aspidoderidae, Aspidoderinae}

\section{Aspidodera raillieti Travassos, 1913}

Hosts. Didelphis aurita Wied-Neuwied, 1826, Philander opossum (Linnaeus, 1758).

Site of infection: large intestine.

Localities. Mambucaba - Angra dos Reis, Barra de Maricá - Maricá, Serra dos Órgãos - Magé, Vales do Pamparrão and Porteira Verde - Sumidouro, Rio de Janeiro Primatology Center - Guapimirim, Glicério - Macaé, Morro de São João Casimiro de Abreu, Rio de Janeiro.

Specimens deposited. CHIOC $\mathrm{n}^{\circ} 33545$ and 33558.

Remarks. Railliet \& Henry (1912), proposed the genus Aspidodera; Travassos (1913), while studying samples of Heterakis sp., found, in coinfection, an unknown aspidoderid worm that was proposed as Aspidodera raillieti. ProENÇA (1937), SKRJABIN $\&$ Schiкновадоva (1947) revised the genus confirming its validity. The first occurrence of $A$. raillieti overseas was that reported by WolfGang (1951) in marsupials of the Trinidad Islands. Further, VICENTE (1966) presented a detailed study of the species of Aspidoderinae, including A. raillieti; PINTO \& Gomes (1980) reported the species parasitizing Philander opossum. SANTos et al (1990) in a new revision of the genus, proposed a key for the identification of the species and considered the cephalic cordons as one of the most reliable systematic character. In Didelphis aurita, the species appeared with a prevalence of $32 \%$ and mean intensity of 51.2; coinfection of $A$. raillieti was with $C$. tentaculata $+T$. turgida and C. tentaculata $+T$. turgida $+V$. hamata or only with $C$. tentaculata. Coinfection of $A$. raillieti was also with $C$. tentaculata $+V$. hamata; C. tentaculata $+T$. turgida + Gongylonemoides marsupialis. The prevalence of coinfection was $4 \%$. In $P$. opossum, $A$. raillieti had a prevalence of $48 \%$, mean intensity of 10.4 , appearing alone in $4 \%$ of the cases and in $36 \%$ of the coinfection with $C$. tentaculata $+V$. viannai.

\section{Cosmocercoidea, Kathlaniidae, Cruziinae}

\section{Cruzia tentaculata (Rudolphi, 1819) Travassos, 1917}

Hosts. Didelphis aurita Wied-Neuwied, 1826, Philander opossum (Linnaeus, 1758).

Site of infection: large intestine.

Localities. Glicério - Macaé, Barra de Marica - Marica, Morro de São João - Casimiro de Abreu, Fazenda Cordeiro São Pedro da Aldeia, Serra dos Órgãos - Magé, Vales do Pamparrão and Porteira Verde - Sumidouro, Rio de Janeiro.

Specimens deposited. CHIOC $\mathrm{n}^{\circ} 33542,33543,33544$, 33571, 33572, 33574, 33575, 33576, 33577 and 33578

Remarks. The species was described by Rudolphi (1819) as Ascaris tentaculata and further included in Oxysoma by SCHNEIDER (1886). Travassos (1917) proposed the family Cruzidae with the type genus Cruzia in which included $C$. tentaculata that was briefly described with the presence of an intestinal cecum, what excluded $C$. tentaculata from specimens of the former Heterocheilidae. Travassos (1922) fully illustrated the species; Caballero (1937) refers to the occurrence of $C$. tentaculata in Didelphis marsupialis mesamericana Allen, 1902 (= D. marsupialis Linnaeus, 1758) in the Mezquital Valley in Mexico and later CabalLero et al. (1944) reports the species in Didelphis marsupialis tabascencis Allen, 1901 (= D. marsupialis 
Linnaeus, 1758) again in Mexico and also in Guatemala. WOLFGANG (1951), POTKAI (1970) affirmed that C. tentaculata commonly parasitizes marsupials in South and Central America. Pinto \& Gomes (1980) also refer to C. tentaculata in Didelphis opossum Larrañaga, 1923 (= Didelphis aurita Wied-Neuwied, 1826) from the Amazon region. The specimens presently studied were closer to those referred by Travassos (1922). In D. aurita, this species showed a prevalence of $68 \%$ and a mean intensity of 75.6 . In $16 \%$ of the cases, coinfection of $C$. tentaculata was observed with $T$. turgida; $A$. raillieti $+T$. turgida; $A$. railliet $+T$. turgida $+V$. hamata and alone in $8 \%$ of these cases; also representing $16 \%$ of the occurrences. C. tentaculata appeared in coinfection with $A$. raillieti $+T$. turgida $+G$. marsupialis; A. raillieti $+V$. hamata and alone in $4 \%$ of these cases. In $P$. opossum, the prevalence was of $48 \%$, mean intensity of 68.6 ; coinfection with $A$. raillieti occurred in $36 \%$ of the animals; with $A$. railliet $+V$. viannai in $4 \%$ and alone in $28 \%$ of the cases.

\section{Physalopteroidea, Physalopteridae, Physalopterinae}

\section{Physaloptera bispiculata Vaz \& Pereira, 1935}

Host: Nectomys squamipes (Brants, 1827).

Site of infection: stomach.

Localities. Barra de Maricá - Maricá, Morro de São João -

Casimiro de Abreu, Rio de Janeiro.

Specimens deposited. CHIOC $\mathrm{n}^{\circ} 31978$ and 31916.

Remarks. SEURAT (1916) described $P$. getula recovered from African Mus musculus Linnaeus, 1758; VAz \& Pereira (1935) found specimens of physalopterids in N. squamipes from São Paulo, SP, that were nominated as $P$. bispiculata. MORGAN (1943) in a key to the species of the genus parasitizing rodents, observed that the original description of $P$. getula even incomplete and misinterpreted, suggested that $P$. bispiculata could be a junior synonym of this species; nevertheless, VICENTE et al. (1982) refer to the occurrence of $P$. bispiculata in N. squamipes from Ilha Grande, Rio de Janeiro. Later, Gomes \& VICENTE (1984) during necropsies of specimens of this same rodent captured in Sumidouro, Rio de Janeiro, found physalopterid nematodes that were compared to the original material studied by VAZ \& PEREIRA (1935); they could observe that the vulvar aperture was located in the first third of the body as referred by Morgan (1943) and thus the synonymy of $P$. bispiculata with $P$. getula was ratified. MAFRA \& LANFREDI (1998), studying specimens of physalopterid nematodes recovered from $N$. squamipes from Rio Bonito, Rio de Janeiro, verified by means of SEM, that the number of caudal papillae and other characters were identical to those referred by VAZ \& Pereira (1935) to P. bispiculata, that, in fact, proved to be a valid species. P. bispiculata appeared with a prevalence of $76 \%$, and a mean intensity of 14 ; it was found alone in $36 \%$ of the cases and in coinfection with $L$. carinii in $12 \%$, to H. epsilon in $8 \%$, to H. epsilon + S. venteli; H. epsilon $+L$. carinii, in $4 \%$ of the occurrences.

\section{Turgida turgida (Rudolphi, 1819) Travassos, 1919}

Host: Didelphis aurita Wied-Neuwied, 1826.

Site of infection: stomach.

Localities. Fazenda União and Morro São João - Casimiro de Abreu, Glicério - Macaé, Mambucaba - Angra dos Reis, Vales Pamparrão and Porteira Verde - Sumidouro, Rio de Janeiro. Specimens deposited. CHIOC $\mathrm{n}^{\circ} 33573$ and 33574.
Remarks. Travassos (1920b) studied the species of Turgida Schulz, 1931 with a key to the subfamilies of Physalopterinae and described T. torresi (Travassos, 1920) Ortlepp, 1922. With respect to $T$. turgida it is referred parasitizing Brazilian opossums with high prevalences. Caballero (1937), Caballero et al. (1944) report to the occurrence of the species in marsupials from Mexico and Guatemala. Wolfgang (1951) referred to T. turgida in South and Central America. The morphometry of our specimens was closest to that presented by Travassos (1920b); the species appeared with a prevalence of 56\%, mean intensity of 12.6 , occurring alone in $16 \%$ of the cases and in coinfection with $C$. tentaculata in $12 \%$; coinfection, either with C. tentaculata $+A$. raillieti or with C. tentaculata $+A$. railliet $+V$. hamata, represented $8 \%$ of the occurrences whereas with $C$. tentaculata $+A$. raillieti $+G$. marsupialis and $V$. hamata $+C$. tentaculata, the species appeared in $4 \%$ of the cases.

\section{Spiruroidea, Gongylonematidae, Gongylonematinae}

\section{Gongylonemoides marsupialis (Vaz \& Pereira, 1934) Freitas \& Lent, 1937}

Host: Didelphis aurita Wied-Neuwied, 1826.

Site of infection: esophagus. Janeiro.

Locality: Fazenda União - Casimiro de Abreu, Rio de

Specimens deposited. CHIOC $\mathrm{n}^{\circ} 33586$ and 33663a-c.

Remarks. The species was proposed as Gongylonema marsupialis by VAZ \& Pereira (1934), on the basis of a female specimen recovered from D. aurita; Freitas \& LENT (1937), during necropsies in specimens of $D$. aurita and Metachirops opossum (Temminck, 1824) [= Philander opossum (Linnaeus, 1758)] found females identical to that described previously as well as males, that presented generic characteristics different from those referred for specimens of Gongylonema Molin, 1857; thus, they proposed the genus Gongylonemoides Freitas \& Lent, 1937 and included the former Gongylonema marsupialis in the new genus. The species appeared with a prevalence of $4 \%$ and mean intensity of 15 and was in coinfection with A. raillieti $+C$. tentaculata $+T$. turgida in the cases of occurrence.

\section{Spiruridae, Spirurinae}

\section{Spirura guianensis (Ortlepp, 1924) Chitwood, 1938}

Host: Philander opossum (Linnaeus, 1758).

Site of infection: esophagus.

Locality: Serra dos Órgãos - Macaé, Rio Janeiro.

Specimens deposited. CHIOC $\mathrm{n}^{\circ}$ 33496, 33550, 33553 and 33562 .

Remarks. The species was described as Protospirura guianensis by ORTLEPP (1924), on the basis of a male specimen from the stomach of a primate from Suriname. CHITwOoD (1938) included the species in Spirura Blanchard, 1849, considering the presence of the ventral "hump", the most outstanding character. QuENTIN (1973) described the life cycle of S. guianensis and affirmed that the species of the genus are distributed among the hosts of ancient origin, mainly insectivores, carnivores, rodents, Neotropical marsupials and primates. Амато et al. (1976) refer the first occurrence of the species in Brazil, parasitizing Philander opossum quica (Temminck, 1825), informing 
that from a single host specimen, more than 200 worms were recovered. PinTo \& Gomes (1980) report to the presence of $S$. guianensis in marsupials from the Amazon Region, ratifying QuENTIN (1973) on what concerns to the parasitism of the species in Brazilian marsupials. The prevalence of this species was of $12 \%$ with a mean intensity of 2.7 .

\section{Filarioidea, Onchocercidae, Onchocercinae}

\section{Litomosoides carinii (Travassos, 1920) Vaz, 1934}

Host: Nectomys squamipes (Brants, 1827).

Site of infection: pleural cavity.

Localities. Barra de Maricá - Maricá and Morro de São João - Casimiro de Abreu, Rio de Janeiro.

Specimens deposited. CHIOC $\mathrm{n}^{\circ} 32403$.

Remarks. Travassos (1920a), described as Filaria carinii nematodes found in the pleural and peritoneal cavities of Sciurus sp. MAzzA (1928) examining nematodes recovered from the peritoneal cavity of Holochilus vulpinus Wagner, 1843 (= Holochilus brasiliensis Desmarest, 1819) from Argentina, described Filaria patersoni Mazza, 1928 [= Litomosoides patersoni (Mazza, 1928) Chitwood, 1932], justifying that the description of the new species was based on the fact that this would be the first of the genus to occur in South America, since the genus was proposed to contain L. sigmodontis from the cotton rat Sigmodon hispidus Say \& Ord, 1825 (ChANDler 1931). VAZ (1934) indicates $L$. carinii as the type species of the genus, on the basis the similarities between $L$. carinii and L. sigmodontis, considered a junior synonym of the former. PINTo et al. (1982) refer to the occurrence of L. carinii in Oryzomys subflavus (Wagner, 1842) and Gomes \& Vicente (1984), in N. squamipes from Sumidouro, Rio de Janeiro, with a prevalence of $45.2 \%$. The prevalence of this species in the same host herein investigated, was of $16 \%$, with a mean intensity of 24.5 and the coinfection was with $P$. bispiculata in $12 \%$ of the cases and with $H$. epsilon $+P$. bispiculata in $4 \%$ of the occurrences.

\section{GENERAL REMARKS}

The South American mammalian fauna has been evolving from ancient autochthonous strains of great diversity and different origins that colonized the continent in different periods, as well (ReIg 1981).

The history of the marsupials in South America goes back to the Didelphidae; these are the most spread and ancient group with fossils dating from the Cretacean and can be found from the southern region of North America to almost all the South American continent (CLEmens 1966, Fox 1971, Sigé 1971, TEDFORD 1974, SIMPSON 1990).

Marsupials of the genus Alphadon Simpson, 1929 have been conventionally considered primitive and ancestral of the existing species (MARSHAL et al. 1990). The first marsupialian species from South America is represented by A. antracinus Simpson, 1929 from a Peruvian Superior Cretacean deposit. (SIGÉ 1971, 1972).

In Brazil, the genera of marsupials proposed by PAULA Couto $(1952,1962,1970)$ for the Superior Pliocene of São José de Itaboraí, reveal a high level of morphological diversities, suggesting that the specimens represent different groups and subfamilies of Didelphidae. The primitive didelphids were mostly omnivorous, feeding on insects, annelids, eggs, amphibians, reptiles, birds, mammals, fruits and juicy parts of vegetables (SIMPSON 1990).

However, the rodents share ancestors that are not included among the South American ancient representatives from the Paleocene and Eocene periods; primitive rodents are known from the fauna of the Tertiary in North America, Eurasia and Africa. Fossil findings show the presence of different forms of this group in the Inferior Oligocene in Patagonia and Bolivia. Some authors (HERSHKOVITZ 1966, 1972, SAVAGE 1974, REIG $1975,1978,1980,1981)$ suggest that the South American rodents derived from an ancient strain that reached South America at the beginning of the Miocene.

Most of the genera in the sigmodontines probably were differentiated during distinct local cladogenetic episodes, from an ancestral strain that reached the north of South America, coming from North America. The settlement in South America could be accomplished by means of transoceanic dispersion, before the establishment of the Panamanian link and the Inferior Miocene was the most probable period in which the migratory process took place. This could have occurred locally in South America in different areas of the Andes, where the Oryzominii, the most primitive Sigmodontini, originally differentiated in Colombia, Ecuador and Venezuela (REIG 1981).

The hosts, as they moved, carried their parasites that, during the evolutionary process, were submitted to mutations and natural selection, since parasites and hosts may interact; the evolution of the parasite is related to the modifications of the host that, generally, evolves to a more adapted organism able to tolerate the parasite; thus, the survival of the parasite depends on that of the host. It is known that long-term parasites are less aggressive to their hosts and when both are adapted to each other, immunological responses tend to be low (FERREIRA 1973).

Helminths, specifically the nematodes, originated from free-living forms to further develop monoxenous or heteroxenous life cycles; the latter is essential for the evolution of nematodes from vertebrates (ChABAUd 1978). According to Chabaud (1954) the intermediate host was a recent or secondary acquisition in the transmission of nematodes that previously had invaded vertebrates and developed by means of monoxenous life cycles. The dispersion of the parasites clearly seems to follow the specialization of a host species in a group; this specialization was not acquired by chance, but, in fact, is due to previous successful infections in host species that have become extinct. Thus, during the mammals age, an outbreak of the Trichostrongylidae nematodes, to which the evolution depends on the dispersion of the hosts, was observed (Durette-Desset 1971, Durette-Desset \& Chabaud 1977).

Humphery-SMith (1983) shows the similarities between the Herpestrongylinae nematodes parasitizing marsupials in North America and the Viannaiinae from South American marsupials; differentiation of specimens representing these subfamilies is based on the the bursal rays and synlophe. Specimens of Didelphis aurita Wied-Neuwied, 1826 and Philander opossum (Linnaeus, 1758) feed on invertebrates, mostly insects, small vertebrates, eggs and fruits. The arthropods, mainly those found in the forest ground are the principal item in the diet of these marsupial species; variations in the height, decomposition degree, humidity and temperature of the forest ground coverage are important aspects to be considered, since these ani- 
mals, using this site, can promote the growth of arthropods (Willis 1976, Lieberman \& Dock 1982, Pearson \& Derr 1986, Lynch et al. 1987).

The nematode Cruzia americana Maplestone, 1930, that occurs in North American marsupials, has a monoxenous life cycle (CRITES 1956 in ANDERSON 1992), whereas the infecting larvae of another nematode Physaloptera sp. a most common parasite of the stomach of marsupials, from the Brazilian Atlantic Forest develop in cockroaches; also, Gongylonematidae nematodes need intermediate hosts, generally beetles, to maintain the life cycles (ANDERSON 1992).

Previous reports confirm the presence of insects in the diet of Akodon cursor (Winger, 1887) (FonseCA \& KiERULFF 1989, Stallings 1989). Fragments of Coleoptera and Hymenoptera were found in specimens of Oryzomys intermedius (Leche, 1886) and Nectomys squamipes (Brants, 1827); the latter also presented parts of spiders. These findings show that the ground coverage of the Brazilian Atlantic Forest plays an important role in the transmission of helminths with heteroxenous life cycles.

Results of the prevalence of the nematodes reported herein are in accordance with previous reports and show the correlation between the number of investigated host specimens and the size of worm burdens yelded, what is a reliable parameter for the evaluation of parasitic loads and their maintenance in the hosts. Moreover, the present data indicate that parasites can serve as biological indicators of the dispersion of hosts in the case of environmental disarrays.

\section{ACKNOWLEDGEMENT}

We are thankful to Bruno Eschenazi Silveira, Laboratório de Imagens, Instituto Oswaldo Cruz, for technical assistance regarding the figures.

\section{REFERENCES}

Almeida, C.R.; A.M.P. AlmeidA; D.P. BRAsiL; J.D. Sobrinho \& M.A.M. LEA. 1986. Estudos do roedor Akodon arviculoides Wagner, 1942 (Cricetidae). Importância nos focos pestosos do Brasil. Memórias do Instituto Oswaldo Cruz, Rio de Janeiro, 81: 409-416.

Амato, J.F.R.; P.T. Castro \& L. Grisi. 1976. Spirura guianensis Ortlepp, 1924, parasita de Philander opossum quica Temminck, 1825 no Estado do Rio de Janeiro, Brasil (Nematoda: Spiruridae). Revista Brasileira de Biologia, Rio de Janeiro, 36: 123-127.

Anderson, R.C. 1992. Nematodes Parasites of Vertebrates: Their development and transmission C A B International, University Press, Cambridge, XIII+578p.

Apa. 1989. Código de ética experimental com animais. Sozed, Rio de Janeiro, 8 p.

Azevedo, C. 1997. O santuário ameaçado da Mata Atlântica. Geográfica Universal, Rio de Janeiro, 265: 23-40.

Bergalo, H.G. 1994. Ecology of a mammal community in an Atlantic Forest area in Southeastern Brazil. Studies on Neotropical Fauna and Environment, Müchen, 29: 197-217.

Bush A.O.; K.D. Laferty; J.M. Lotz \& A.W. Shostak. 1997. Parasitology meets ecology on its own terms: Margolis et al. revisited. Journal of Parasitology, Lawrence, 83: 575583.
Caballero, C.E. 1937. Nematodos de algunos vertebrados del Valle del Mezquital, HGO. Annales del Instituto de Biologia, México, 8: 189-200.

Caballero, C.E.; M. Bravo-Hollis \& M.C. Cerecero. 1944. Estudios helmintológicos de la region oncocercosa del México y de la Republica de Guatemala. Nematoda. Segunda parte (1), (2). Annales del Instituto de Biologia, México, 15: 389407.

Cerqueira, R.; R. Gentile; E.A.S. Fernandes \& P.S. D'Andrea. 1993. A five-year population study of an assemblage of small mammals in southeastern Brazil. Mammalia, Paris, 57: 507517.

Chabaud, A.G. 1954. Sur le cycle évolutif des spirurides et de nématodes ayant une biologie comparable. Valeur systématique des caractères biologiques. Annales de Parasitologie Humaine et Compareé, Paris, 29: 42-88; 206-249; 358-425.

. 1978. Keys to genera of the superfamilies Cosmocercoidea, Seuratoidea, Heterakoidea and Subuluroidea 6, p. 1-71. In: R.C. Anderson, A.G. Chabaud \& S. Wilmot (Eds). Keys to the nematode parasites of vertebrates. England, Commonwealth Agricultural Bureax, Farmhan Royal, Bucks, $71 \mathrm{p}$.

Chandler, A.C. 1931. New genera and species of nematode worms. Proceedings of United States National Museum, Washington, 78: 23.

Chaves, G. 1997. Mata Atlântica. Ontem, hoje e amanhã. Germinis, Boletim Informativo do Conselho Federal de Biologia, Brasília, 1 (3): 1-8.

CHItwood, B.G. 1938. The status of Protospirura vs. Mastophorus with a consideration of the species of these genera, p. 115118. In: Instituto Oswaldo Cruz (Ed.). Livro Jubilar do Professor Lauro Travassos. Rio de Janeiro, Instituto Oswaldo Cruz, 589p.

Clemens, W.A. 1966. Fossil mammals of the type Lance Formation, Wyomning. Part II, Marsupialia, University of California Public Geological Science, Wyomming, 66: 1122.

Copobianco, J.P. 1997. Conservação da Mata Atlântica. Germinis, Boletim Informativo do Conselho Federal de Biologia, Brasília, 1 (3): 1-8.

Durette-Desset, M.C. 1968. Helminthes de marsupiaux américains Trichostrongyloidea. Bulletin de la Societé Zoologique de France, Paris, 93: 581-597.

. 1969. Nematodes héligmosomes d'Amerique du Sud. IV. Description de Longistriata hoineffae sp. nov. parasite de Cricètides, et étude du système des aretes cuticulares de $L$. epsilon Travassos, 1937, et L. dollfusi Diaz-Ungria, 1963. Bulletin du Muséum National D'Histoire Naturelle, $2^{\text {ème }}$ série, Paris, 41: 328-337.

. 1971 Essai de classification des nematodes héligmosomes. Correlation avec la paléobiogeographie des hôtes. Bulletin du Muséum National D'Histoire Naturelle, Paris, A 69: 1-126.

Durette-Desset, M.C. \& A.G. Chabaud. 1977. Essai de classification des nématodes Trichostrongyloidea. Annales de Parasitologie Humaine et Compareé, Paris, 52: 539-558.

Ferreira, L.F. 1973. O fenômeno parasitismo. Revista da Sociedade Brasileira de Medicina Tropical, São Paulo, 7: 261277. 
FonseCA, G.A.B. \& M.C.M. KierulfF. 1989. Biology and natural history of Brazilian Atlantic Forest small mammals. Bulletin of Florida State Museum of Biological Science, Gainesville, 34: 99-152.

Fox, R.C. 1971. Marsupial mammals from the early Campanian Milk River Formation. In: D.M. КeRMACK \& K.A. KeRMACK (Eds). Early Mammals Society, Alberta, 50 (Supp. 1): 145-164.

FreitAs, J.F.T. \& H. Lent. 1935. Quelques variations et anomalies bursaires observés chez Viannaia viannai, Trav., 1914 et $V$. hamata Trav., 1914. Revista de Medicina e Cirurgia, Rio de Janeiro, 9: 23-258.

— 1937. Notas sobre Gongyloneminae Hall, 1916 (Nematoda Spiruroidea). Memórias do Instituto Oswaldo Cruz, Rio de Janeiro, 32: 299-303.

Gomes, D.C. 1979. Contribuição ao conhecimento dos helmintos parasitos de marsupiais no Brasil, da Coleção Helmintológica do Instituto Oswaldo Cruz - Trematoda. Atas da Sociedade de Biologia do Rio de Janeiro, Rio de Janeiro, 20: 33-43.

Gomes, D.C.; R.M. Lanfredi; R.M. Pinto \& W. Souza. 1992. Description of Trichuris travassosi sp. nov. (Nematoda: Trichurinae) from a Brazilian rodent, by light and scanning electron microscopy. Memórias do Instituto Oswaldo Cruz, Rio de Janeiro, 87 (Suppl. I): 1-10.

Gomes, D.C. \& J.J. Vicente. 1984. Helmintos parasitos de Nectomys squamipes (Brants) do Município de Sumidouro, RJ. Memórias do Instituto Oswaldo Cruz, Rio de Janeiro, 79: 67-73.

Guerrero, R. 1985. Trichostrongyloidea parasitos de mamíferos silvestres de Venezuela. II Revision del genero Viannaia Travassos, 1914. Memoria de la Sociedad de Ciencias Naturales La Salle, Caracas, 124: 9-47.

Hershrovitz, P. 1966. Mice, land bridges and Latin American fauna interchange, p. 725-751. In: R.L. WENzEL \& V.J. TIPTON (Eds). Ectoparasites of Panama. Chicago, Field Museum of Natural History, 543p.

. 1972. The recent mammals of the Neotropical Region: a zoogeographic and ecological review, p. 311-331. In: A. KLEAST; F.C. ERK \& B. Glass (Eds). Evolution, Mammals and Southern Continents. Albany, State University of New York Press, 543p.

Humphery-Smith, I. 1983. An hypothesis on the evolution of Herpetostrongylinae (Trichostrongyloidea: Nematoda) in Australian marsupials, and their relationships with Viannaidae, parasites of South American marsupials. Australian Journal of Zoology, Collingwood, 31: 931-942.

Lieberman, S. \& C.F. Dock. 1982. Analysis of the leaf litter artropod fauna of a lowland tropical evergreen forest site (La Selva, Costa Rica). Revista de Biologia Tropical, San Jose, 30: 27-34.

LYNCH, J.F.; A.K. JOHANSON \& E.C. BALINSKY. 1987. Spatial and temporal variation in the abundance and diversity of ants (Hymenoptera: Formicidae) in the soil and litter layers of a Maryland forest. American Midland Naturalist, Notre Dame, 119: 31-44.

Mafra, A.C.A.T. \& R.M. LANFredi. 1998. Reevaluation of Physaloptera bispiculata (Nematoda: Spiruroidaaea) by light and scanning electron microscopy. Journal of Parasitology, Lawrence, 84: 582-588.
Marshal, L.G.; J.A. Case \& M.O. Woodburne. 1990. Phylogenetic relationships of the families of marsupials, p. 433-505. In: H.H. Genoways (Ed.). Current mammalogy. New York, Plenum Press, 596p.

MazzA, A.S. 1928. Filarideo sp. nov. de la cavidad peritoneal de la rata de los cañaverales de Tabacal, Salta. Boletin del Intituto de Clinica Quirurgica de Buenos Aires, Buenos Aires, 4: 628 .

Morgan, B.B. 1943. The Physaloptera (Nematoda) of Rodents. Washington Collection, Washington, 5: 99-106.

Neveu-Lemaire, M. 1936. Traité d'helminthologie médicale et vétérinaire, Vigot Frères, Editeurs, Paris: 728-729.

OrtLepP, R.J. 1924. On a collection of helminths from Dutch Guiana. Journal of Helminthology, Wallingford, 1: 15-40.

Paula-Couto, C. 1952. Fossil mammals from the beginning of the Cenozoic in Brazil. Marsupialia: Didelphidae. American Museum Novititates, New York, 1567: 1-26.

. 1962. Didelfídeos fósiles del Paleoceno de Brasil. Revista del Museu Argentino de Ciencias Naturales "Bernardino Rivadavia" Zoologia, Buenos Aires, 8: 135166.

1970. New fossil marsupials from the Riochican of Brazil. Anais da Academia Brasileira de Ciencia, Rio de Janeiro, 41: 19-34.

Pearson, D.L. \& J.A. Derr. 1986. Seasonal patterns of lowland forest floor arthropod abundance in southeastern Peru. Biotropica, St. Louis, 18: 244-256.

PinTo, R.M. 1978. Sobre Hassalstrongylus dessetae sp. n. (Nematoda, Trichostrongyloidea). Atas da Sociedade de Biologia do Rio de Janeiro, Rio de Janeiro, 19: 59-61.

PINTO, R.M. \& D.C. Gomes. 1980. Contribuição ao conhecimento da fauna helmintológica da região Amazônica. Nematódeos. Atas da Sociedade de Biologia do Rio de Janeiro, Rio de Janeiro, 21: 65-79.

Pinto, R.M.; D.C. Gomes; L.C. Muniz-Pereira \& D. Noronha. 2002. Helminths of guinea pig, Cavia porcellus (Linnaeus), in Brazil. Revista Brasileira de Zoologia, Curitiba, 19 (Supl. 1): 261269.

Pinto, R.M.; A. Kohn; B.M.M. Fernandes \& D.A. Mello. 1982. Nematodes of rodents in Brazil, with descripition of Aspidodera vicentei sp. nov. Systematic Parasitology, Hague, 4: 263-267.

Pinto, R.M.; J.J. Vicente; D. Noronha; L. Gonçalves \& D.C. GoMES. 1994. Helminth parasites of conventionally maintained laboratory mice. Memórias do Instituto Oswaldo Cruz, Rio de Janeiro, 89: 33-40.

PоткAY, S. 1970. Disease of the opossum (Didelphis marsupialis): A review. Laboratory Animal Care, Lamont, 20: 502-511.

ProençA, M.C. 1937. Revisão do gênero Aspidodera Railliet \& Henry, 1912. (Nematoda: Subuluroidea). Memórias do Instituto Oswaldo Cruz, Rio de Janeiro, 32: 421-438.

Quentin, J.C. 1969. Étude de nématodes Syphacia parasites de Rongeurs, Cricetidae Sud-Américains et de leurs corrélations biogeographiques avec certaines espèces neartiques. Bulletin du Museum National D'Histoire Naturelle, $2^{\text {ème }}$ Serie, Paris, 41: 909-925.

. 1973. Présence de Spirura guianensis (Ortlepp,1942) chez les marsupiaux neotropicaux. Cycle évolutif. Annales 
de Parasitologie Humaine et Compareé, Paris, 48: 117 133.

Railliet, A. \& A. Henry. 1912. Quelques nématodes parasites des reptiles. Bulletin de la Societé de Pathologie Exotique, Paris, 5: 251-259.

ReIG, O.A. 1975. Diversidad, historia evolutiva y dispersión de los roedores cricétidos sudamericanos. Acta Cientifica Venezuelana, Caracas, 26 (Suppl 1): 7.

. 1978. Roedores cricétidos del Plioceno superior de la provincia de Buenos Aires (Argentina). Publicaciones del Museu de Ciencias Naturales "Lorenzo Scaglia", Mar del Plata, 2: 164-190.

. 1980. A new fossil genus of South American cricetid rodents allied to Wiedomys, with an assessment of the Sigmodontinae. Journal of Zoology, Cambridge, 192: 267-281.

- 1981. Monographiae Naturae. Teoria del origen y desarrollo de la fauna de América del Sur. Monogr Naturae. Publicaciones del Museu de Ciencias Naturales "Lorenzo Scaglia", Mar del Plata, 1: 1-161.

REY, L. 1993. Non-human vertebrate host of Schistosoma mansoni and schistomosomiasis transmission in Brazil. Research and Reviews in Parasitology, Valencia, 53: 13-25.

Rodrigues-Silva, R.; J.R. Machado-Silva; N.F. Faerstein; H.L. Lenzi \& L Rey. 1992. Natural infection of wild rodents by Schistosoma mansoni parasitological aspect. Memórias do Instituto Oswaldo Cruz, Rio de Janeiro, 87 (Suppl. I): 271276.

RudolPHI, C.A. 1802. Beobachtungen über die Eingeweidewürmer. Wiegmans Archive für Zoologie 2: 1-67.

1819. Entozoorum synopis cui accedunt mantissa duplex et indices locupletissini. Berolini, $\mathrm{X}+811 \mathrm{p}$.

SANTOS, C.P.; H. LENT \& D.C. Gomes. 1990. The genus Aspidodera Railliet and Henry, 1912 (Nematoda: Heterakoidea): Revision, new synonyms and key for species. Revista Brasileira de Biologia, Rio de Janeiro, 50: 1017-1031.

SAVAGE, J.M. 1974. The isthmian link and the evolution of Neotropical mammals. Contribuitions in Science of the Natural History Museum of Los Angeles County, Los Angeles, 260: 1-51.

SCHNeIDER, A. 1866. Monographie der Nematoden. Berlin, XIII+357p.

Seurat, L.G. 1916. Sur les oxyures des mammifères. Comptes Rendus de la Societé de Biologie, Paris, 79: 64-68.

SIGÉ, B. 1971. Les Didelphoidea de Laguna Umayo (form. Vilquechico Crétacé supérieur, Péru) et le peuplement marsupial de l'Amerique du Sud. Comptes Rendus de la Academie de Science, Paris, 273: 2479-2481.

ـ 1972. La faune de mammifères du Crétacé supérieur de Laguna Umayo (Andes péruviennes). Bulletin du Muséum National D'Histoire Naturelle, Paris, 19: 373-409.

Simpson, G.G. 1990. Marsupials, p 63-79. In: G.G. Simpson (Ed.). Splended isolation the curious history of South American mammals. New Haven and London, Yale University Press, 266p.

SkRjabin, K.I. \& N.P. Shiкhobalova 1947. Revision of the systematics of nematode family Heterakidae. Dokladi Akademiya na Naukite, Moscou, 58: 718-721.

StalLiNGS, J.R. 1989. Small mammals inventories in an Eastern Brazilian park. Bulletin of the Florida State Museum of
Biology and Science, Gainesville, 34: 153-200.

TEDFord, R.H. 1974. Marsupial and new paleogeogragraphy, p. 109-126. In: C.A. Ross (Ed.). Paleogeographic Provinces and Provinciality. Tulsa, R.C.A. Society of Economy, Paleontology and Mineralogy Special Papers Ed., vol. 21, 233p.

Travassos, L. 1913. Sobre as espécies brazileiras da subfamília Heterakinae Railliet \& Henry. Memórias do Instituto Oswaldo Cruz, Rio de Janeiro, 9: 1-34.

. 1914. Tricostrongylideos brazileiros. Brasil Médico, Rio de Janeiro, 34: 325-327.

. 1917. Contribuição para o conhecimento da fauna helmintológica brasileira X. Sobre as espécies do gênero Túrgida. Memórias do Instituto Oswaldo Cruz, Rio de Janeiro, 12: 73-77.

. 1918 [1919]. Trichostrongylideos brazileiros. Revista de Ciência, Rio de Janeiro, 3: 191-205.

1920a. Filaria carinii, sp. nov. Revista de Ciência, Rio de Janeiro, 3: 188-189.

.1920b. Contribuições para o conhecimento da fauna helmintológica brasileira. X. Sobre as espécies do gênero Turgida. Memórias do Instituto Oswaldo Cruz, Rio de Janeiro, 12: 73-77.

1922. Contribuição para o conhecimento do fauna helmintológica brasileira. XVI - Cruzia tentaculata (Rud.,1819) Memórias do Instituto Oswaldo Cruz, Rio de Janeiro, 14: 88-94.

. 1937a. Revisão da Família Tricostrongylidae Leiper, 1912. Monografias do Instituto Oswaldo Cruz, Rio de Janeiro, 1: VII + 512 pp.

. 1937b. Contribuição ao conhecimento da filogenia dos Oxyuroidea (Nematoda). Memórias do Instituto Oswaldo Cruz, Rio de Janeiro, 32: 607-613.

VAZ, Z. 1934. Ackertia gen. nov. for Litomosa burgosi De La Barrera, 1926, with notes on the synonymy and morphological variations of Litomosoides carinii (Travassos, 1919). Annals of Tropical Medicine and Parastology, London, 28: 143-149.

Vaz, Z. \& C. Pereira. 1934. Two new parasitic worms of Didelphis aurita Skrjabinofilaria pricei sp. nov. and Gongylonema marsupialis sp. nov. Journal of the Washington Academy of Sciences, Washington, 24: 54-56p.

. 1935. Some new Brazilian nematodes. Transactions of the Microscopical Society, Menacha, 54: 36-40.

VICENTE, J.J. 1966. Revisão da subfamília Aspidoderinae (Skrjabin \& Shikobalova, 1947) (Nematoda). Memórias do Instituto Instituto Oswaldo Cruz, Rio de Janeiro, 64: 131-161.

Vicente, J.J.; D.C. Gomes \& N.A. Araujo Filho. 1982. Alguns helmintos de marsupiais e roedores da Ilha Grande, Estado do Rio de Janeiro. Atas da Sociedade de Biologia do Rio de Janeiro, Rio de Janeiro, 23: 4-3.

WiLLIS, E.O. 1976. Seasonal changes in the invertebrate litter fauna on Barro Colorado Island Panama. Revista Brasileira de Biologia, Rio de Janeiro, 36: 643-657.

Wolfgang, R.W. 1951. Studies on the endoparasitic fauna of Trinidad mammals. Canadian Journal of Zoology, Ottawa, 29: 352-375.

Received in 07.IV.2003; accepted in 17.XI.2003. 